Article

\title{
Between Queen Esther and Marie-Antoinette: Courtly Influence on an Esther Scroll in the Braginsky Collection
}

Sara Offenberg (D)

Citation: Offenberg, Sara. 2022. Between Queen Esther and

Marie-Antoinette: Courtly Influence on an Esther Scroll in the Braginsky Collection. Arts 11: 40. https:// doi.org/10.3390/arts11020040

Academic Editor: Iñaki Bergera

Received: 14 January 2022

Accepted: 14 February 2022

Published: 4 March 2022

Publisher's Note: MDPI stays neutral with regard to jurisdictional claims in published maps and institutional affiliations.

Copyright: (C) 2022 by the author. Licensee MDPI, Basel, Switzerland. This article is an open access article distributed under the terms and conditions of the Creative Commons Attribution (CC BY) license (https:// creativecommons.org/licenses/by/ $4.0 /)$.

\begin{abstract}
Department of the Arts, Ben Gurion University of the Negev, P.O.B 653, Beer Sheva 84105, Israel; offenber@bgu.ac.il
\end{abstract}

\begin{abstract}
There is an Esther scroll in the Braginsky manuscript collection (Braginsky Collection Megillah 7) that was produced in Alsace in the second half of the eighteenth century. The manuscript has not yet caught the attention of scholars, and I would like to shed some light on its artistic design in the context of French noble society. Although its illustrations appear naïve, they are typical of other Esther scrolls of that time and place. Based on contemporary art and textual evidence, I focus on the depiction of women in the megillah, and I argue that the scroll portrays an intimate understanding of the cultural ambience and the decorum of Parisian high society and bourgeoisie during Marie-Antoinette's lifetime.
\end{abstract}

Keywords: Esther scroll; Marie-Antoinette; Jewish art; illuminated manuscripts

Throughout the centuries, Jewish art has reflected a close affinity with the dominant society wherein the artifacts were produced, and as art historians, we can learn much therefrom about the mutual exchanges between the Jewish and non-Jewish communities. This is especially true when it comes to illuminated Esther scrolls. ${ }^{1}$ This essay focuses on a fascinating instance of an Esther scroll that depicts the contemporary fashion and social manners at the court of Marie-Antoinette. In the Braginsky manuscript collection, we find an Esther scroll (Braginsky Collection Megillah 7) that was produced in Alsace in the second half of the eighteenth century. The entire manuscript is available online: https:/ / braginskycollection.com/ajaxzoom/single.php?zoomDir=/pic/BCS/BCS_ 7\&zoomFile=BCS_007_001.jpg (retrieve 13 February 2022). Clearly, the Alsace Esther scroll manuscript has not yet caught the attention of scholars, as the only relevant publication that I know of is the Braginsky Catalogue, which notes:

"Each column of text is bordered above and below by bands of scrolling vines.

Lively figures, several shown strolling with walking sticks in hand and others gesturing, are interspersed with human busts, owls, and a gargoyle. These fanciful images appear to bear no specific relationship to the Esther story". (Deitsch and Mintz 2009)

This Esther scroll, which measures $94 \mathrm{~mm} \times 2430 \mathrm{~mm}\left(3.7^{\prime \prime} \times 95.7^{\prime \prime}\right)$, was copied on parchment, on five membranes, and in 15 text columns, each of which is flanked by yellow borders and decorated with flowers. Although its illustrations appear naïve, they are typical of other Esther scrolls from the same time and place. The scroll depicts an intimate understanding of the cultural ambience and the decorum of Parisian high society and bourgeoisie during Marie-Antoinette's lifetime.

Only a few Esther scrolls produced in eighteenth-century Alsace are extant, and, except for the scroll under discussion, most are described in Bezalel Narkiss's Index of Jewish Art. For example, Esther Scroll with Octagonal Text Panels, Alsace (?), first quarter of the eighteenth century, Gross Family Collection, No. 081.012.037; ${ }^{2}$ Illustrated Esther Scroll with Roundels, Alsace (?), first quarter of the eighteenth century, Amsterdam, Jewish Historical Museum, M000440; ${ }^{3}$ the Jerusalem, Israel Museum, no. MS 182/081, ${ }^{4}$ all of 
which differ in style as well as in artistic design from the manuscript that we address here. To the best of my knowledge, only one other scroll, Esther Scroll with Sunflowers, Alsace (?), mid-eighteenth century, Paris, Musée d'art et d'histoire du Judaïsme Paris (MAHJ), inv. D.98.04.077.CL (former number $\mathrm{Cl}$ 17503), ${ }^{5}$ reflects a similar style, but it differs in the choice of scenes, and the details of the figures' costumes are more elaborate and refined. A "sister" scroll was sold at the Sotheby's "Important Judaica Including Property from the Jewish Community of Amsterdam (NIHS)" auction in New York on 13 December 2006, lot $186 .{ }^{6}$ The Hebrew text in this scroll is inscribed in columns framed in rectangles. The panels in the upper margins are separated by roundels containing Yiddish commentary based on the text of the Book of Esther. There are human figures in the spaces between the text panels, and, in one case, there is a narrative scene of the hanging of Haman's sons. While these figures resemble those in the Braginsky scroll, there are no busts. In the Paris scroll, we also find painted narrative episodes from the Book of Esther as well as single figures above and below the text panels.

In the first image of the Braginsky Esther scroll, we see a man (perhaps Mordechai) wearing a black tricorne hat, dressed in a fashionable suit, and pointing with his right hand to the next column of text, which tells of Queen Vashti. We then come upon a nearly obliterated image of a woman (Figure 1) attired in a blue dress, a blue hat, and a red and yellow upper garment astride a pitchfork, which she holds with both hands, very much resembling a witch. ${ }^{7}$ This depiction may refer to a midrashic exegesis in Esther 2:11: "Every single day, Mordecai would walk about in front of the court of the harem, to learn how Esther was faring and what was happening to her". Esther Rabbah 6.8, a medieval commentary on the story, explains that Mordechai was concerned that other women in the palace might practice witchcraft on Esther. ${ }^{8}$ Some Rabbinic sources note that Vashti was harming the daughters of Israel and that her punishment, among others, was that she had a tail:

"This teaches [us] that the wicked Vashti would take the daughters of Israel, and strip them naked, and make them work on Shabbat. ... The verse states: 'But the Queen Vashti refused to come' (Esther 1:12). The Gemara asks: Since she was immodest, as the Master said above: The two of them had sinful intentions; what is the reason that she did not come? ... The angel Gabriel came and fashioned her a tail". (Babylonian Talmud Megillah 12.2)

Thus, this could be the image of Vashti as a vindictive rejected woman, revealing her identity as a wicked witch.

Next, we see two male figures, one wearing a yellow hat and dressed in a blue coat, short red trousers, and yellow stockings, standing with his arms spread out; the other, who is holding a mace and walking, is wearing a different type of yellow hat and is dressed in a blue upper garment, short red trousers, a red fabric belt, and white stockings. We identify the next image of a woman as Hadassah, also known as Esther, prior to her arrival at the palace (Figure 2). This simple-looking maiden wears a white cap with ruffled edges, a fluffy red shirt, a yellow skirt with a corselet with black ribbons, and above it a plain white apron typical of traditional costumes in Alsace. ${ }^{9}$ The next figure is of a man with a big belly walking with a cane toward the left, dressed in a red coat, a yellow hat, and yellow stockings. He has long, curly brown hair, but we cannot distinguish his facial figures. 


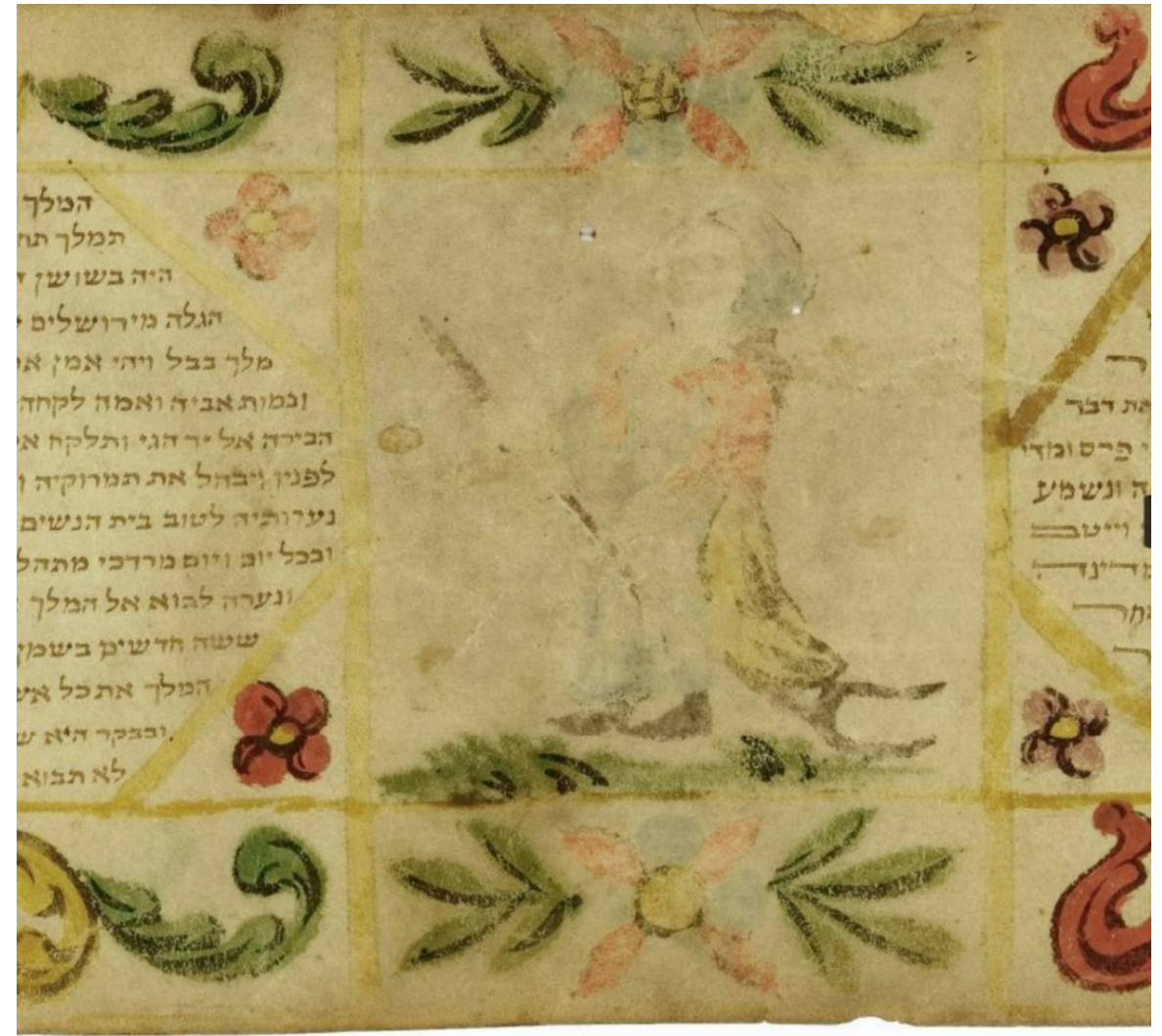

Figure 1. Queen Vashti, Esther scroll from the Braginsky Collections (Braginsky Collection Megillah 7), Alsace, the second half of the eighteenth century.

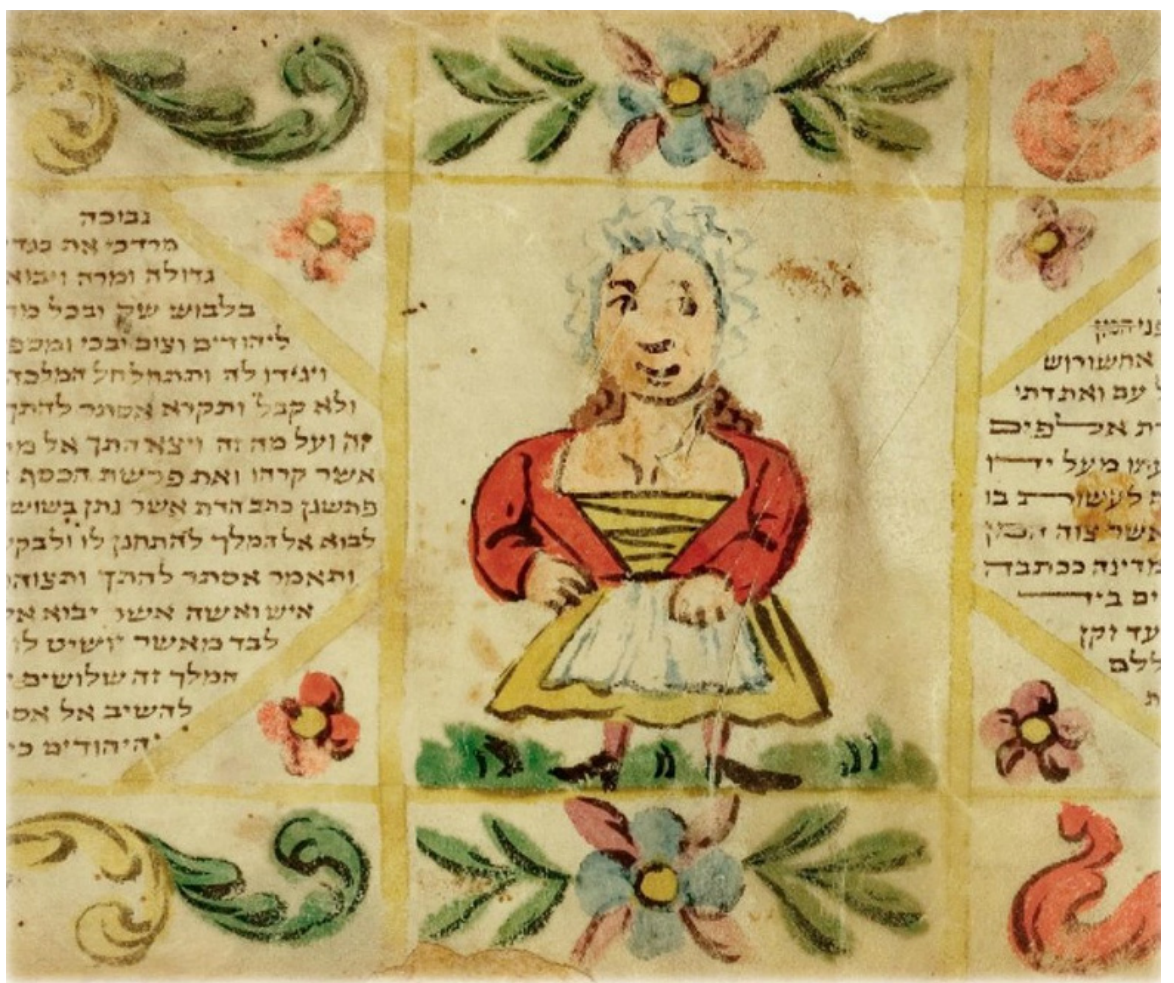

Figure 2. Haddasah, Esther scroll from the Braginsky Collections (Braginsky Collection Megillah 7), Alsace, the second half of the eighteenth century. 
The image alongside the text that mentions Zeresh, Haman's wife, is of a woman wearing a large, red hat and a blue and yellow dress that shows deep cleavage (Figure 3). Her facial features are those of an elderly woman and are almost grotesque, ${ }^{10}$ with a large nose and a smile that takes up almost a third of her face. The next scene shows a large house with red brick roof and a tall chimney. The depiction after that shows an owl with a white toupee and a ruff typical of the eighteenth century. ${ }^{11}$ Next to the text of Chapter 8 , which tells about King Ahasuerus extending the golden scepter to Esther, we see Queen Esther as a bust, sporting an elaborate coiffure, ${ }^{12}$ deep cleavage, and a beneficent smile (Figure 4). Here I stress that, as opposed to almost all other figures in the scroll, this woman figure is depicted as a bust, and I argue that this choice of depiction is meaningful in the historical and social context at the time that this scroll was written.

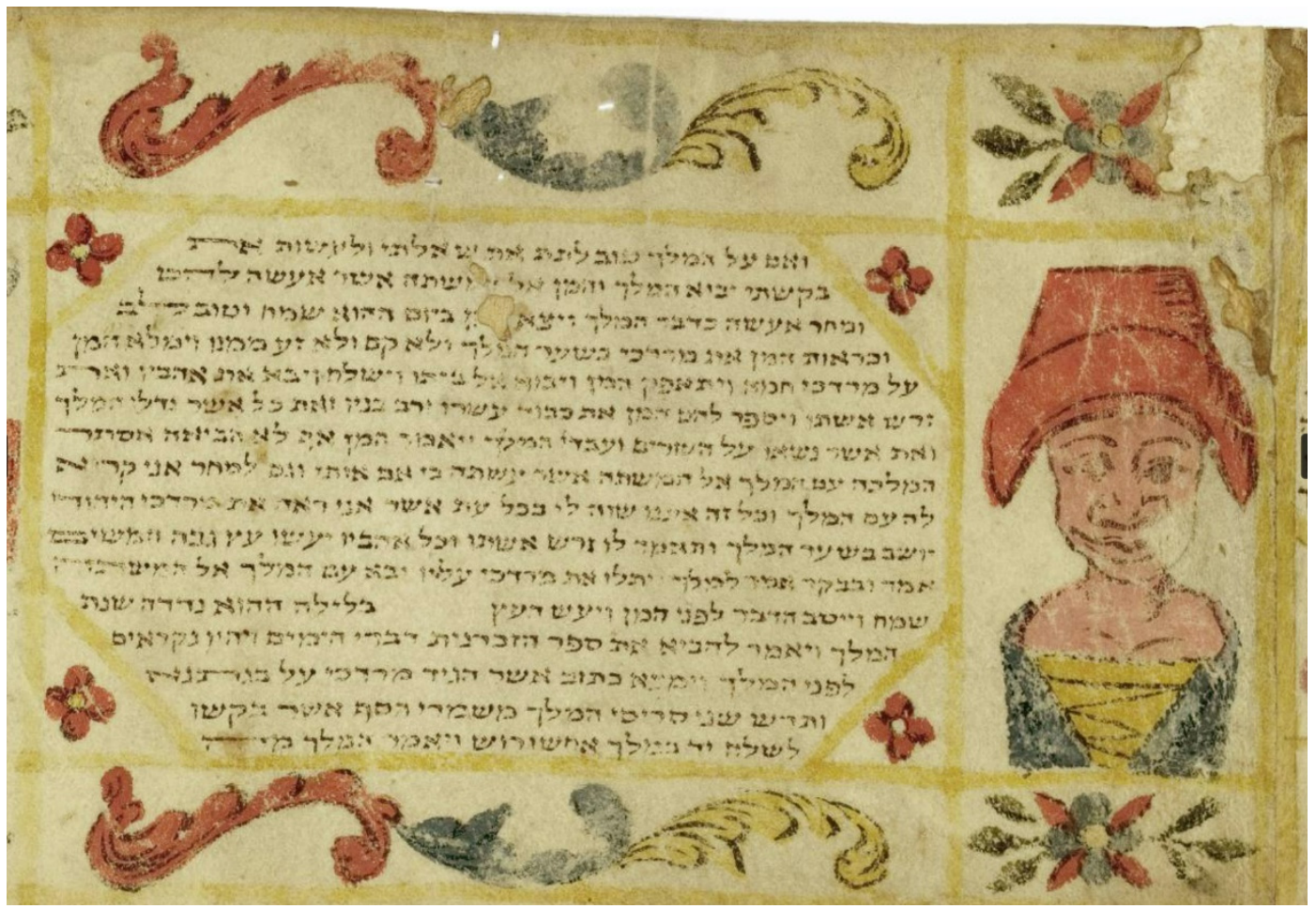

Figure 3. Zeresh, Esther scroll from the Braginsky Collections (Braginsky Collection Megillah 7), Alsace, the second half of the eighteenth century.

My intention here is to connect the depictions of Queen Esther in this scroll to the famous busts made for the French court, which then became popular in salons. ${ }^{13}$ To do so, I rely on Ronit Milano's research, which addresses the portrait bust and eighteenth-century French cultural politics (Milano 2012; Idem 2015). According to Milano, the then-new artistic formula featuring a semi-nude breast and a smile, which became popular during the second half of the eighteenth century and appeared in portraits of respectable women subjects, corresponded to the new interest in the sexual view of women and in their dual perception as both erotic and maternal. The smile was associated with maternal happiness deriving from a woman's relationship with her children and husband. Such an example is visible in the official portrait bust of Marie-Antoinette, created by Félix Lecomte and exhibited in the 1783 Salon (Figure 5). ${ }^{14}$ In the context of the royal court, portrait busts of women celebrating family values and domestic happiness were viewed not merely as actual representations of motherhood, but also as political messages of devotion to the nation. Such depictions suited the ideal image of the noble yet erotic and, at the same time, dedicated wife. Here we find a Jewish understanding of these motifs, as the image of Esther reflects all three conventions of the time: bust figure, deep cleavage, and a beneficent smile. 


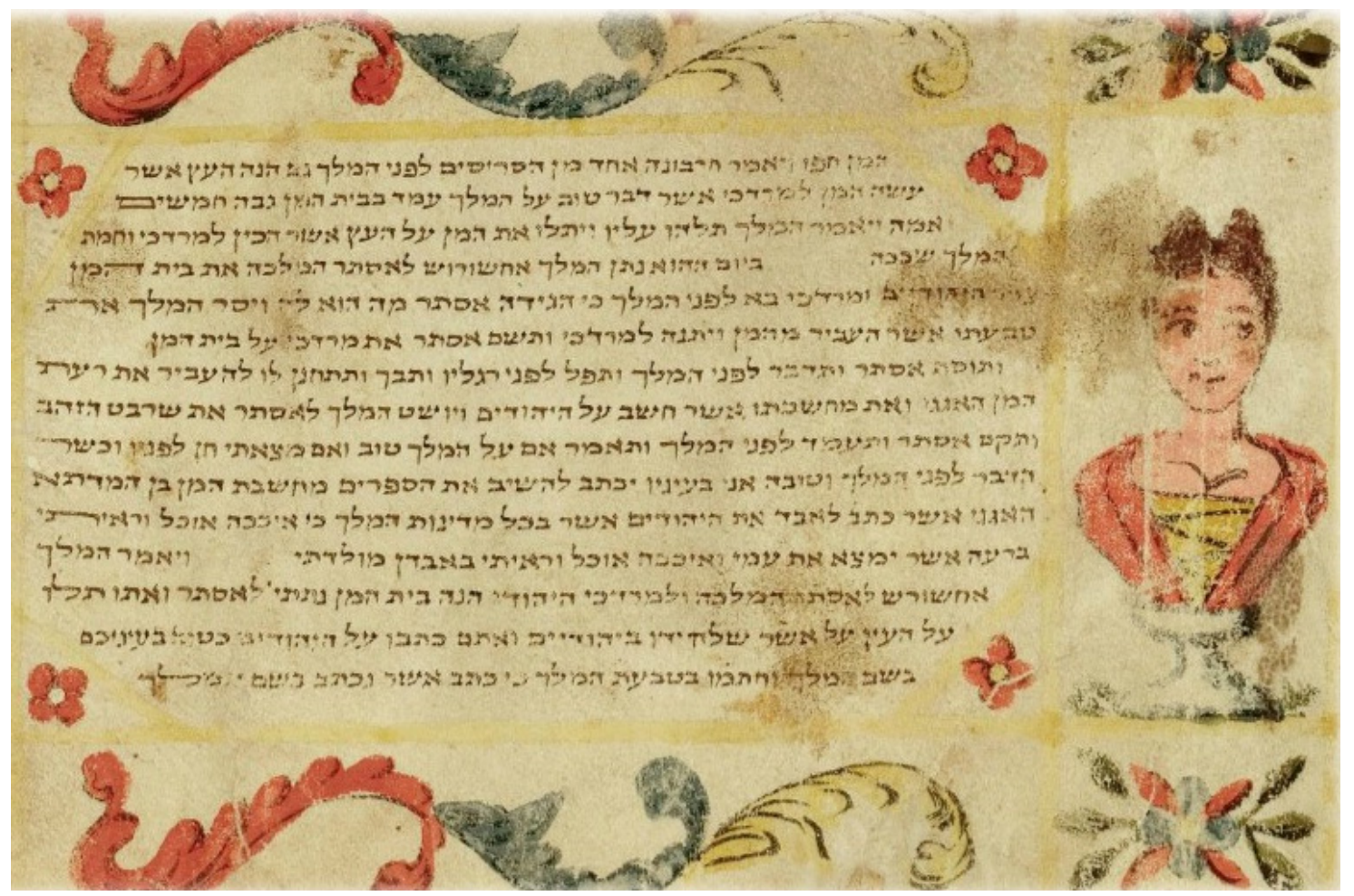

Figure 4. Queen Esther, Esther scroll from the Braginsky Collections (Braginsky Collection Megillah 7), Alsace, the second half of the eighteenth century.

Zeresh's image shows a clear difference between her portrayal and that of Queen Esther; the first seems like caricature of a fashionable upper-class woman, whereas the second bears the status symbols of nobility and, more importantly, of the ideal wife finding happiness within her domesticity and her virtuous conduct in society. These qualities, evident in portrait busts from the French court, were adopted and implemented in this Esther scroll.

Toward the end of the scroll, two owls hold wine cups, and "[ .. . owls, dressed in ruffs and hats and holding wine goblets ... may well be an illustration of a European proverb 'drunk as an owl.'"15 We should also remember that one of the customs of the holiday of Purim is to drink until the point of drunkenness, that is, to drink until one can no longer tell the difference between villainous Haman and virtuous Mordecai. Such a reference is also found at the end of the aforementioned Paris scroll, depicting two men raising goblets of wine. ${ }^{16}$ The owls adorn the sides of the text of Esther 8.15-16: "And the city of Shushan rang with joyous cries. The Jews enjoyed light and gladness, happiness and honor". Although there has been a negative convention regarding owls and their connection to the blindness of the Jews since the Middle Ages (Strickland 2003), Zvi Orgad recently showed how owls may represent the persecuted Jews seeking redemption in early modern Jewish art. ${ }^{17}$ Based on this theory, and looking at the owls in our scroll, they may hint at the exceptional reversal and salvation that occurred historically on Purim, according to Esther 9.1: "And so, on the thirteenth day of the twelfth month-that is, the month of Adar-when the king's command and decree were to be executed, the very day on which the enemies of the Jews had expected to get them in their power, the opposite happened, and the Jews got their enemies in their power". This process of redemption originates in the celebration of the month of Adar, which commemorates the great salvation in which the people of Israel faced tremendous danger but emerged victorious. The last image in this scroll, appearing just after the recounting of the names of Haman's ten executed sons, is another bust quite different from the one discussed earlier, which might well be a portrayal of Haman as a troll, which was a very well-known creature in the culture of the time. ${ }^{18}$ As with Zeresh, it is the negative image of the ideal noble portrait bust. 


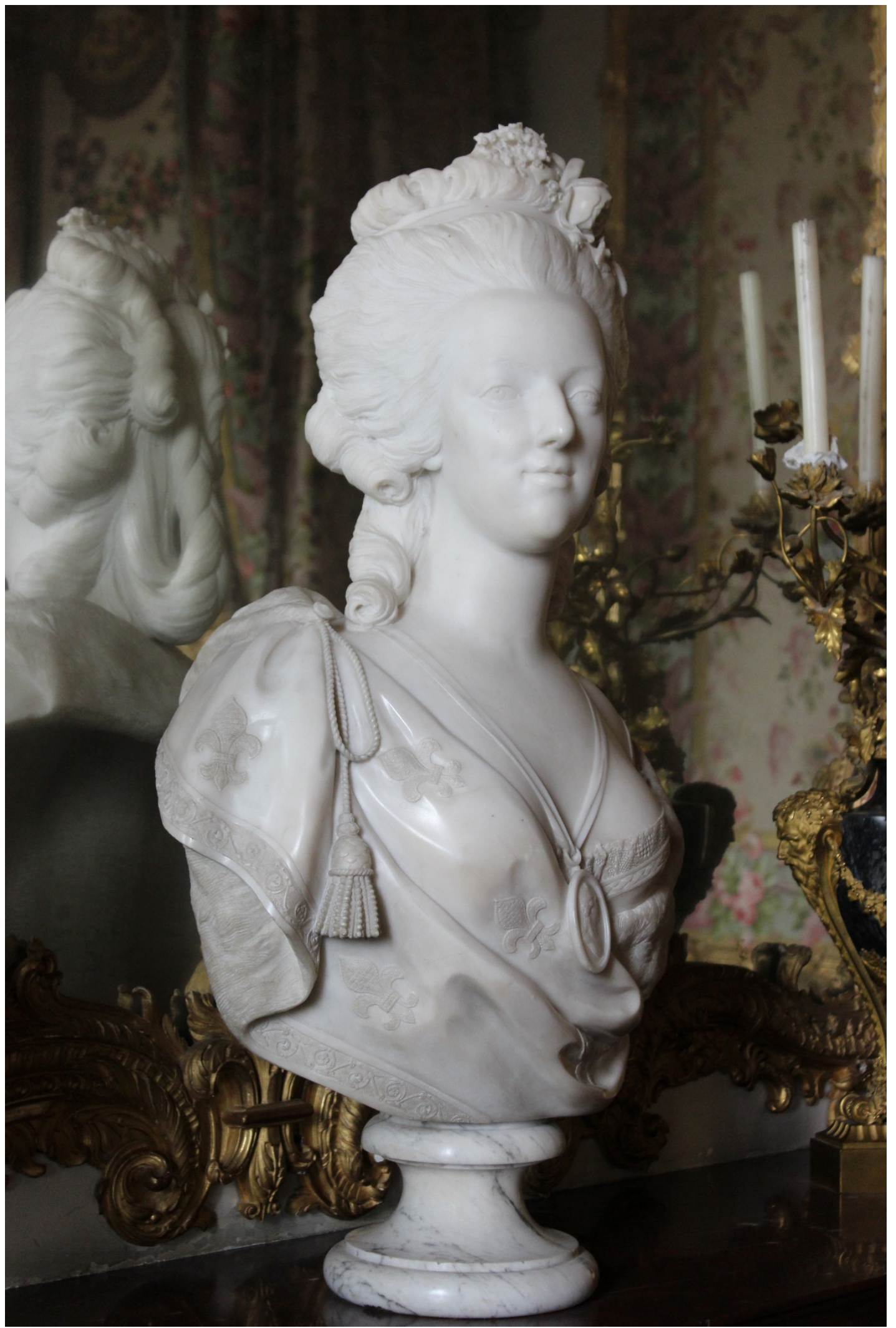

Figure 5. Félix Lecomte, Marie-Antoinette, 1783, marble, h. $86 \mathrm{~cm}$, Versailles, Château de Versailles et de Trianon. https://commons.wikimedia.org/wiki/File:Palace_of_Versailles_19.jpg (retrieve 13 February 2022). 
Thus, we have seen four images of women where the scroll's Jewish patron and/or artist adopted symbols of the contemporary noble Christian society. In looking at the portrayals of the four women figures (Queen Vashti, Hadassah, Zeresh and Queen Esther) in the Braginsky Collection Esther Scroll, we note a difference in the way the wicked women and an ideal woman are portrayed. The dissimilarity between the depictions appears even more blatant when we look at the bust. The emphasis on Esther as a role model for an ideal queen and wife was created by using an eighteenth-century French artistic convention of a bust portrait of a woman with cleavage and a beneficent smile. Perhaps the scroll was meant to be a wedding gift, so that the theme of the ideal women might have fit this purpose. We know that from the fifteenth century, some of the owners of illuminated books were women who received them as wedding presents, ${ }_{1}^{19}$ but for the moment, we do not have enough information on the origin of this scroll, or by and for whom it was commissioned.

Funding: This research was funded by Gerda Henkel Stiftung grant number AZ54/V/18.

Institutional Review Board Statement: Not applicable.

Informed Consent Statement: Not applicable.

Data Availability Statement: Not applicable.

Conflicts of Interest: The authors declare no conflict of interest.

\section{Notes}

On the relation between Christian art and Esther scrolls see Carruthers (2020); Epstein (2015); Mann and Chazin (2007); Sabar (2012); Wiesemann (2014).

2 On the website of The Bezalel Narkiss Index of Jewish Art, Object ID: 35194: https: / / cja.huji.ac.il/gross/browser.php?mode=set\& id=35194, accessed on 13 January 2022.

3 On the website of The Bezalel Narkiss Index of Jewish Art, Object ID: 39595: https: / / cja.huji.ac.il/gross/browser.php?mode=set\& id=39595, accessed on 13 January 2022.

4 On the website of The Bezalel Narkiss Index of Jewish Art, Object ID: 200: https: / / ja.huji.ac.il/ browser.php?mode=set\&id=200, accessed on 13 January 2022.

$5 \quad$ Klagsbald (1981); and on the website of The Bezalel Narkiss Index of Jewish Art, Object ID: 34758: https:// cja.huji.ac.il/browser. php? mode=set\&id=34758, accessed on 13 January 2022.

6 On Sotheby's website https://www.sothebys.com/en/auctions/ecatalogue/2006/important-judaica-including-property-fromthe-jewish-community-of-amsterdam-nihs-n08266/lot.186.html, accessed on 13 January 2022.

7 On women as witches riding on pitchforks, see Zika (2017). On Jewish fear of witchcraft and its representation in Jewish art in Alsace, see Raphael (2004).

8 On a critical edition of Midrash Esther Rabbah see Tabory and Atzmon (2014).

9 Doerflinger (1979); Wilcox (2011), Plate 8.

10 According to Tamar Eilam Gindin, the name Zeresh "is a name of an Avestan demoness. The demoness Zaurvi-nominative (subject case) Zaurviš—represents old age (the name shares a Farsi root with "geriatrics" and "gerontology") and poisons plants". Gindin (2016).

On dress in the eighteenth-century, such as a white toupee and a ruff see McNeil (2017).

On contemporary hairstyles, see Ribeiro (2002); Weber (2006).

On Jews imagining themselves as nobility in illuminated manuscripts, see Offenberg (2019).

Félix Lecomte, Marie-Antoinette, 1783, marble, h. $86 \mathrm{~cm}$, Versailles, Château de Versailles et de Trianon.

Deitsch and Liberman Mintz, “Esther Imagined," 268. On this phrase, see Apperson (2006). See also (Freddy and Weyl 1977). I thank the anonymous reviewer for this reference.

See image on the website of The Bezalel Narkiss Index of Jewish Art, Object ID: 34758: https: / / cja.huji.ac.il/browser.php?mode= alone\&id=328143, accessed on 13 January 2022.

Orgad (2020). I thank the anonymous reader of this article for this reference.

On troll, see Duggan et al. (2016); Thorpe (1851).

On Hebrew illuminated manuscripts as marriage gifts for women see Offenberg (2019); Weinstein (2006); Idem (2014). See also Horowitz and Cohen (1990); Horowitz (1986). 


\section{References}

Apperson, G. L. 2006. The Wordsworth Dictionary of Proverbs. Ware: Wordsworth Reference.

Carruthers, Jo. 2020. The Politics of Purim: Law, Sovereignty, and Hospitality in the Aesthetic Afterlives of Esther. London: T\&T Clark.

Deitsch, Elka, and Sharon Liberman Mintz. 2009. Esther Imagined: Second Half of the Eighteenth Century Alsace. In A Journey through Jewish Worlds: Highlights from the Braginsky Collection of Hebrew Manuscripts and Printed Books. Edited by Evelyn M. Cohen, Sharon Liberman Mintz and Emile G. L. Schrijver. Amsterdam: Bijzondere Collecties, Universiteit van Amsterdam; Zwolle: Distributed by Waanders, pp. 268-69.

Doerflinger, Marguerite. 1979. Découverte Des Costumes Traditionnels en Alsace. Colmar-Ingersheim: Editions SAEP, pp. 7-8.

Duggan, Anne E., Donald Haase, and Helen Callow. 2016. Folktales and Fairy Tales: Traditions and Texts from around the World. Santa Barbara: Greenwood, pp. 124, 293, 350-53, 480.

Epstein, Marc Michael. 2015. Skies of Parchment, Seas of Ink: Jewish Illuminated Manuscripts. Princeton: Princeton University Press.

Freddy, Raphaël, and Robert Weyl. 1977. Juifs en Alsace: Culture, Société, Histoire. Toulouse: Privat, p. 32.

Gindin, Tamar Eilam. 2016. The Book of Esther Unmasked. Kefar Sava: Zeresh Books, p. 153.

Horowitz, Elliot, and Evelyn Cohen. 1990. In Search of the Sacred: Jews, Christians, and the Ritual of Marriage in the Later Middle Ages. Journal of Medieval and Renaissance Studies 20: 225-49.

Horowitz, Elliot. 1986. 'The Way We Were': Jewish Life in the Middle Ages. Jewish History 1: 75-90. [CrossRef]

Idem. 2014. Marriage Rituals Italian Style: A Historical Anthropological Perspective on Early Modern Italian Jews. Leiden and Boston: Brill. Idem. 2015. The Portrait Bust and French Cultural Politics in the Eighteenth Century. Boston: Brill.

Klagsbald, Victor. 1981. Catalogue Raisonné de la Collection Juive du Musée de Cluny. Paris: Musée des Thermes et de l'Hôtel de Cluny, pp. 68-70.

Mann, Vivian B., and Daniel D. Chazin. 2007. Printing, Patronage and Prayer: Art Historical Issues in Three Responsa. Images: A Journal of Jewish Art and Visual Culture 1: 91-97. [CrossRef]

McNeil, Peter, ed. 2017. A Cultural History of Dress and Fashion. In 4 In the Age of Enlightenment. London: Bloomsbury Publishing, pp. 90-92.

Milano, Ronit. 2012. Decent Exposure: Bosoms, Smiles and Maternal Delight in Pre-Revolutionary French Busts. Sculpture Journal 21: 43-56. [CrossRef]

Offenberg, Sara. 2019. Up in Arms: Images of Knights and the Divine Chariot in Esoteric Ashkenazi Manuscripts of the Middle Ages. Los Angeles: Cherub Press, pp. 15-17.

Orgad, Zvi. 2020. Prey of Pray: Allegorizing the Liturgical Practice. Arts 9: 3. [CrossRef]

Raphael, Freddy. 2004. Popular Art of the Jewish Communities in Alsace at the Time of their Entry into the Modern Period. Studia Rosenthaliana 37: 133-45. [CrossRef]

Ribeiro, Aileen. 2002. Dress in Eighteenth-Century Europe, 1715-89. New Haven: Yale University Press, p. 56.

Sabar, Shalom. 2012. A New Discovery: The Earliest Illustrated Esther Scroll by Shalom Italia. Ars Judaica 8: 119-36.

Strickland, Debra Higgs. 2003. Saracens, Demons, E Jews: Making Monsters in Medieval Art. Princeton: Princeton University Press, pp. 136-37.

Tabory, Joseph, and Amnon Atzmon, eds. 2014. Midrash Ester Rabbah: Critical Edition. Jerusalem: Schechter Institute, pp. 117, 230.

Thorpe, Benjamin. 1851. Northern Mythology, Compromising the Principal Traditions and Superstitions of Scandinavia, North Germany, and the Netherlands: Compiled from Original and Other Sources, 3 Vols. London: Edward Lumley, vol. II, pp. 148-58.

Weber, Caroline. 2006. Queen of Fashion: What Marie Antoinette Wore to the Revolution. New York: Holt, pp. 95-96.

Weinstein, Roni. 2006. Gift Exchanges during Marriage Rituals among Italian Jews in the Early Modern Period: A HistoricAnthropological Reading. Revue des Etudes Juives 165: 485-521. [CrossRef]

Wiesemann, Falk. 2014. The Esther Scroll. Cologne: Taschen.

Wilcox, R. Turner. 2011. Folk and Festival Costume: A Historical Survey with Over 600 Illustrations. Mineola: Dover Publications.

Zika, Charles. 2017. Recalibrating Witchcraft through Recycling and Collage: The Case of a Late Seventeenth-Century Anonymous Print. In The Primacy of the Image in Northern European Art, 1400-1700: Essays in Honor of Larry Silver. Edited by Debra Cashion, Henry Luttikhuizen and Ashley West. Leiden and Boston: Brill, pp. 391-404. 